\title{
Lexical Borrowings in Our Press and the Possibility of Their Replacement with Albanian Words
}

\author{
Albulena Lala Zeqiri \\ Master of Education-Management in Education, University of Prishtina, Kosovo \\ Email: lena-fa@live.com

\section{Veneranda Xhelili Kryeziu} \\ Master's student in English Language, University of Tetova, Macedonia \\ Email: venerandaxh@hotmail.com
}

Doi:10.5901/mjss.2017.v8n2p177

\begin{abstract}
The present paper treats the influence of foreign words in our press and the possibility of their replacement with Albanian words. The Albanian Language used today in our press suffers from a reckless use of excessive borrowings that is significantly distorting its nature. Its natural that languages cooperate with one another through borrowing and loaning words but there must also be specific criteria and responsibilities for such borrowings. It is the duty of all subjects involved to give the right direction to this issue : Purification of Albanian language from foreign words and its enrichment with native words. Therefore, in this paper, we intend to identify non-Albanian words that wander in our language, and invite Albanian language writers how to write the Albanian language in Albanian. The methods implemented in this research are: historical method, the method of comparative analysis, gathering and selection of material (books, foreign language dictionaries and Albanian newspapers), analysis, comparison and description of the material. Results expected from this research are to bring into evidence borrowed words from other languages in our press, their identification and study, comparison of many words used today in our press, possibilities of replacement of such words with relevant Albanian words while using words from our country folk treasure, which is an inexhaustible source of enrichment of Albanian language.
\end{abstract}

Keywords: borrowing, press, purify, replacement, Albanian word etc.

\section{Introduction}

Albanian language purification from foreign words is an important issue for the Linguistics. Many writers and Albanian linguists in early times have tried to clean the Albanian language from unnecessary usage of foreign words.

Prof. Dr. Eqrem Çabej in a paper summary "Issues of Literary norms" (1980) mentions old authors who have worked for the purity of language such as Gjon Buzuku, Pjetër Bogdani, Pashko Vasa, Nikollë Keta, Engjëll Mashi, Jeronim De Rada, Panajot Kupitori, Anastas Kulluridi, Naum Veqilharxhi, Kristoforidhi, Naim\&Sami Frashëri, Jani Vreto, Luigj Gurakuqi, Aleksandër Xhuvani, Mati Lagoreci. On language purification have also worked Prof. Androkli Kostallari, academic Idriz Ajeti, academic Jani Thomai, prof. Emil Lafe, academic Gjovalin Shkurtaj, Dr. Engjëll Agoni, Dr. Murat Bejta and many others.

An important work that can help us in the replacement of foreign words is the work of Aleksander Xhuvani "For the purity of Albanian language" published in 1968. Then we have the Dictionary "Albanian word instead of a foreign word" published in 1989 by Shaqir Berani \& Haxhi Birinxhiku, "Dictionary for the purity of Albanian language" published by AS (Academy of Science) of RA (Republic of Albania) (1998). Later "The Albanological Treatise" by Dr.Qemal Murati published in 2005 which contains many borrowed words in Albanian especially by the press. This author has also published the dictionary of language mistakes "The language of media" in 2008. The book "How to speak and write correctly" of Dr. Bahtiar Kryeziu" (2006) and so many other works.

Despite many writings, works and different research conducted to the day that support the Albanian word, there is still a continuous use of foreign words such as Latin, Slavic, Turkish, Greek, and lately English.

The beginning of the paper features in general the borrowed lexicon in Albanian language, later on the role of the press in avoiding foreign words, the enrichment of Albanian from the country folk treasure and at the end some examples of foreign words used in our press. 


\section{Borrowed Lexicon in Albanian Language (General Overview)}

The leading figure of Albanian language Çabej in a summary of works mentions that the language reflects a nationality and that the richness and purity of the language shows also the cultural level of the nation (Çabej, 1980: 5). According to Beran, language is considered to be a nation's property therefore everybody should care and work for the benefit of its language and people (Berani, 1980: 266).

Dhirmo stresses that Albanian language excels in its originality, sustainability and its capability to express clearly, accurately even the tiniest nuances of meaning. It is normal that the Albanian language as other languages, continues to develop and have good relationship with other languages through taking in new words (Dhirmo, 1983: 289). Albanian language was in early contact with other languages with influence therefore Beran claims that borrowed words in early phases are impossible or hard to be replaced with Albanian (Berani, 1983: 163). Goçi mentions that the press is using words such as: universitet (Eng. university), partizan (Eng. partisan), kompani (Eng. company), satelit (Eng. satellite), teleskop (Eng. telescope), rëntgen (Eng.roentgen), etc, because they do not have adequate corresponding words in Albanian (Goçi, 1983: 291).

Meanwhile according to Çabej, the relationship of Albanians with others, especially the neighboring people have played a role not only for the language but for the Albanian history as well. Being in contact with other languages many foreign words, from different fields. were taken in. This was a problem first treated by Gustav Majeri, a great Albanian linguist of its time. "This scholar in the Introduction of the Etymology dictionary of Albanian language, published in Strasbourg in 1891, places this statistic of basic Albanian words in the viewpoint of their source. Of 5140 basic words that the dictionary contains, 1420 turn out to be Latin and Roman, 540 Slavic, 1180 Turkish, 840 new Greek and only 400 inherited from the early Indo-European Albanian, while for the 720 remaining, he says he failed in his attempts to discover them" (Çabej, 1987: 69).

Berisha states that the Albanian language is in continuing contact with other languages and this contact was increased by the rapid development of information technology, raise of the need for trade and economic relations, the need of international cooperation in many fields as in all languages of the world but, particularly in Kosovo and Albania, the influence was due to the establishment of a new political and social reality. Borrowing of foreign words was often helped by their usage in the media (Berisha, 2011: 83). According to Ismajli in order to lay an ambush to these words there is a need of fundamental changes of Albanian language learning in the schools, and also raising awareness and linguistic culture in the mass media (Ismajli, 2011: 82).

But according to Beran the amount of borrowings often depends on the nature of the journalistic article, scientific article, or school text. It is known that when complicated scientific topics are treated, complicated and less comprehensive words are used (Berani, 1980: 265).

\section{The Role of the Press in Avoiding Foreign Words}

"The language of the press preceded further in embracing the unified literary norm, it became as a laboratory with live activity in processing, implanting and spreading of it" (Thomai, 1988: 159).

The media plays a significant role in the acquisition and stabilization of the unified literary language, but we must admit that there are many articles characterized by massive usage and unnecessary need of foreign words (Berani, 1983: 6). According to Goçi the press often spreads foreign words instead of fighting them e.g. : finish (Eng. finish), avantazh (Eng.advantage), mesazh (Eng. message), garant (Eng. guarantee), sinjal (Eng. signal), recepcion (Eng. reception), iniciativ (Eng. initiative), start (Eng. start), telespektator (Eng.televiewer), akoma (Eng. still), bile (Eng.even), etc. (Goçi, 1983: 292). Or according to Murat, words like: live, bye-bye, black-out, fly by plane, etc. (Murati, 2005: 147).

"Albanian language in public use today is as twice jeopardized from the pressure of great foreign languages in an open society and from the inner pressure of media and politicians, that with uncontrolled use of words and foreign structures, often artificial, have touched this language on its vital core. For example our politicians and intellectuals use the words:

elektorati (electorate) - zgjedhësit; viti elektoral (electoral year), shtet elektoral (electoral state), fushatë elektorale (electoral campaign), ringu elektoral (electoral ring), katarsist (catharsis) - i pastër; lëvizja katarsiste (catharsis movement); prioritete (priority) - përparësi; progres (progress) - përparim; suport (support) - mbështetje; inkompetent (incompetent)- jokompetent; informal - joformal, joligjor; burime konfidenciale (confidential source) - burime të rezervuara, etc. even though these words can be spoken in Albanian (Murati, 2005: 80). 
The use of foreign words depends on the responsibility of the one who writes or from quoting of politicians or others that use foreign words. But according to Kryeziu, print media and media in general should have an assigned criteria in codification of spoken and written language that would affect in increasing the language culture. In some countries and since 1996 in Albania too, specialized organs and commissions have been established in order to care for the development and progress of National culture. There could be organized competitions also and offering rewards, as in some European countries for all those who within a year don't make language mistakes in a newspaper or other means of information. In our case, to be rewarded those who do not use foreign words that have Albanian adequate corresponding words (Kryeziu, 2006: 77). Along the linguists for the language purification, writers, translators, publicist etc, have been a great help and still continue to be ("Dictionary for the purity of Albanian language", 1998, 5).

Through examples from daily print media studied by few authors, we will see how much foreign words are being used in our newspapers:

Aparencë (appearance) -(Alb. dukje, nga pamja) "Cheating through democratic appearance" (Panorama, 22.6.2005, 24); bipolar - (Alb. dypalëshe, me dy pole të kundërta) "Political prejudice from old bipolar principles" (Gazeta Ballkan, 14.9.2005); check point - (Alb. pikë kontolli) "The person whose house was made a check point" (tittle Lajm 17.1.2005); fragjil (fragile) - (Alb. i brisht) "Albanians between the European fragility and mandatory Americanization" (tittle, Fakti, 7.9.2005); luk (Look) - (Alb. bukuri, hijeshi, pamje), "Danish look in downtown Tirana" (tittle, Dita, 17.1.2005); news - (Alb. risi, lajm) "The Tirana mayor is no "news" anymore and this is not a coincidence" (Koha Jonë, 16.3.2005); online - (Alb. në linjë, drejtëpërdrejt) "Health departments control heart rates online" (tittle, Shekulli, 24.1.2005);

protektor (protector) - (Alb. mbrojtës, përkrahës) "International protectors have no reason to object Republic of Kosovo" (Express, 15.2.2005); respondent - (Alb. përgjegiës) "Respondents have the most faith in intellectuals" (Koha Ditore, 1.10.2005) (Murati, 2005: 95). Agjendë-a (agenda) - (Alb. rend dite) "This was one of the significant projects that had been earlier in the agenda of many capital projects) (Koha ditore, 30.9.2010, 6); penetroj, penetrim (penetration) (Alb. përshkoj, depërtoj), " ...the penetration is $6 \mathrm{~cm}$ only" (Koha ditore, 8.10.2010, 7); konfidencial-e (confidential)- (Alb. burime, çështje të rezervuara) "...this is confidential and their regulations will not allow (Zëri, 24.9.2010, 13);

sempliste (simple) - (Alb. e thjeshtë, e njëanshme)" With this simple logic the divisions are born and deepened..." (Zëri, 27.9.2010, 11); sekular-e - shekullore "... a state with majority Muslims and strict secular constitution" (Koha Ditore, 30.9.2010, 17) etj. (Mulaku, 2011: 86).

\section{The Enrichment of Albanian Dictionary from Dialects, Sub Dialects, and our Speaking as a Good Possibility for the Albanian Language Purification}

"The richness of our lexical treasure of folk language is great and abundantly, therefore there is a possibility of replacement of foreign words with native words" (Bejta, 1983: 114).

"The treasure of word and expressions of our literary language is in continuous movement, it develops and enriches with a rapid rhythm. Around 80 thousand units have been submitted in the Institution of Language and Literature processed with scientific criteria". Here are some examples:

Gunabër/ë - dress made of wool for little girls ; gjinish/e - clay soil (pa gurë-no rocks);

mag/ë - spider-web; nok/ë - wool leftovers after we comb it; parator - leader;

përtokëz - part of the crop that remains on the ground after we harvest it;

sqepator - woodpecker; syrazi - face to face; mjalcoj - I'm sweetening it;

rrematisem - angry; and many other words (Sinani \& Bulo, 1988: 312).

\section{Today's Albanian Language in Some of Our Newspapers}

This time we have chosen some daily newspapers that are mostly read in Kosovo to see how many foreign words are used within an article, words that can be written in Albanian. E.g: Aset (Assets) - (Alb. pjesë) "There is no data of what the company is and what assets it possesses", (Epoka e re, 27.12.2011, 7); avantazh (advantage) - (Alb. epërsi) "Advantages that were created for the development of local businesses..." (Epoka e re, 27.12.2011, 8); bord (board) - (Alb. këshill) "In the meeting held on Thursday the members of the board have evaluated it as the most successful in the competition ..."(Koha Ditore, 24.2.2012, 7); dekor (decor) - (Alb. zbukurim) "Although Topi was invited to participate in the ceremony he was planned to be used only as a decor"(subtitle, Shekulli, 3.3.2012, 5);

dialog (dialogue) - (Alb. bisedim) "This is exactly the reason why through dialogue the life of people has started to 
improve" (Kosova sot, 27.12.2011, 2); final - (Alb. fund, përfundim)"...to take the final form and be sent to the assembly before January 22-nd..." (Kosova sot, 27.12.2011, 5); illegal -(Alb. joligjor) "... are coordinated with illegal structures in north of the country" (Kosova sot, 27.12.2011, 3); import - (Alb. blerje) "While the year 2010 had less imports from Serbia,..."(Zëri, 27.12.2011, 6); kreativ (creative) - (Alb. krijues) "...does not offer any creative idea for the development of the party"(Epoka e re, 27.12.2011, 4); megaloman (megalomaniac) -(Alb. mendjemadh) "... with elements of megalomania expressions... (Epoka e re, 27.12.2011, 5); partneritet (partnership) - (Alb. bashkëpunim) "In all the agreements that were reached in partnership with Washington and Brussels, Kosovo has always come out as a winner" (Koha Ditore, 24.2.2012, 4); performancë (performance) - (Alb. paraqitje) "...this government has showed and continues to show a weak performance..."(Kosova sot, 27.12.2011, 12); sensitiv-e - (Alb. i, e ndjeshme) " He too refused to talk claiming the topic to be sensitive." (Koha Ditore, 24.2.2012, 3); sokak (neighborhood) - (Alb. lagje) "...comparing to the horizontal it was 40-50 centimeters taller, depending on the width of the neighborhood." (Epoka e re, 27.12.2011, 10); sovran (sovereign) - (Alb. i pavarur) "So the Kosovo government although sovereign authority ..."(Kosova sot, 27.12.2011, 11); subvencion (subsidy) - (Alb. ndihmë) "Subsidies will be fixed for the heads of milk cows."(subtitle, Koha Ditore, 24.2.2012, 9); targë (plate) - (Alb. tabelë) "For people who travel with vehicle plates RKS there will be issued temporary plates..." (Bota Sot, 27.12.2011: 3); valide (valid) - (Alb. e vlefshme) "Initially he said that it is valid and that Kosovo's presentations in the SC of UN are conducted based on this resolution ..."(Koha Ditore, 24.2.2012, 2) etc.

\section{Data Analysis}

During our work we provided the necessary literature, reading, selection and underlining the sentences, words of interest for this paper, later few daily newspapers were selected, finding foreign words and corresponding Albanian words from different dictionaries. Later, an article from each newspaper was selected, which were read, underlined the foreign words, and later words from the article were counted while separating Albanian words and foreign words that have the possibility to be replaced with Albanian. At the end through the help of the computer program excel, the percentage of foreign words and Albanian words was determined in every article selected.

\section{Results and Discussion}

If we analyse words of different articles from different newspaper we get these results:

In the newspaper "Epoka e re", published on 27.12.2011, page 9, in the article "The retirees against their law", there are 365 words in total, 351 or $96,16 \%$ are Albanian and 14 or $3.84 \%$ are foreign words that can be replaced with Albanian words. Words that can be replaced in this article are: skemë (scheme) - plan, a line where the main points of something are displayed, a plan according to which something is going to be built; parlament (parliament)-(Alb. kuvend); draftligj (daft bill) -(Alb. projektligj); diskriminim(discrimination) - (Alb. kufizim i së drejtës), restriction of the right; sociale (social) - (Alb. shoqërore);

absolutisht (absolutely)-(Alb. plotësisht); aprovohet (approved)- (Alb.miratohet); koalicion (coalition) - (Alb. lidhj), a temporary agreement between states, parties, etc. Peticion (petition) -(Alb. lutje, kërkesë).

In the newspaper "Kosova sot", published on 27.12.2011, page 6, in the article "Growth of the global economy, independently from Europe" there are 132 words in total, 121 or $91.67 \%$ are Albanian and 11 or $8.33 \%$ are foreign. Words that can be replaced in this article are: sondazh (survey) - (Alb. vëzhgim); recesion (recession) -(Alb. rënie, largim, tërheqje); globale (global) - (Alb. botërore);

stoge (stocks) - (Alb. rezerva të mallit), accumulated goods in warehouses that are usually sold slowly; rikuperim(recovery) -(Alb. shërim); menaxher (manager) -(Alb. udhëheqës); asete (assets) -(Alb. pjesë); investim (investment) - (Alb.shpenzim), investment of capital in something .

In the newspaper "Koha ditore" published on 24.2.2012, page 19, in the article "Kosovo wins the right to its feasibility study", there are 435 words in total, 395 or $90.80 \%$ are Albanian words and 40 foreign words or $9.20 \%$. Foreign words in this article:

kompromis (compromise) -(Alb. marrëveshje); fizibilitet (feasibility) -(Alb. projekt studimi);

referohet (refer) - (Alb.kumtohet); rezolutë (resolution) -(Alb. vendim); denominim (not nominated) - (Alb. mosemërim);

dialog (dialogue)- (Alb.bisedim); lansim(launch) -(Alb. mësyerje), the release of a news; ekskluzivisht (exclusively)-(Alb. veçanërisht);

konkluzionet (conclusions) - (Alb. përfundimet); draft (draft)-(Alb. projekt); stabilizim (stabilization)-(Alb. qetësim, qëndrueshmëri); 
asocim (association) - (Alb. shoqërizim); definim (definition) -(Alb. përcaktim); ratifikim(ratification) -(Alb. miratim); parlament (parliament)-(Alb. kuvend ); anonimitet (anonymous) - (Alb. e panjohur, pa emër); komunitet (community) (Alb. bashkësi).

In the newspaper "Shekulli" published on 3.3.2012, page 4, in the article "President Topi gathers the Ambassadors and reads the declaration of Lezha" there are 369 words in total, 350 are Albanian or $94.85 \%$ and 19 foreign words, or $5.15 \%$. Foreign words in this article are: bojkotoi (boycott)- (Alb. kundërshtoi, nuk u pajtua; president (president) (Alb.kryetar); presidencë (presidency)- (Alb. kryesi); lutje);

preferoi (prefer) - (Alb. pëlqeu, parapëlqeu); seli (residency) - (Alb. qendër); apeloi (appeal) -(Alb. bëri thirrje,

reflektim(reflection) -(Alb. pasqyrim); mesazh (message)-(Alb. porosi); akredituar (accredited) - (Alb. ndajbesuar, besuar).

In the newspaper "Zëri" published on 19.9.2012, page 18, in the article "The government leases $3 \mathrm{~km}$ of beach in Dhërmi", there are 383 words in total, 359 Albanian words or $93.73 \%$ and 24 foreign or $6.27 \%$. Foreign words in this article are:

Koncesion (concession) -(Alb. lejim, marrëveshje), an agreement between a capitalist state and a large private entrepreneurship; plazh (beach) - (Alb.ranishtë); konfirmim (confirmation)-(Alb. ripohim, vërtetim); detaje (details)-(Alb. hollësi);

konsiston (consists) - (Alb. qëndron) ; bonus (bonus)- (Alb. përfitim); kontraktues(contractor) - (Alb. sipërmarrës) he who builds a contract; firmos (sign) -(Alb. nënshkruan); tender (tender) - (Alb. ankand, ofertë, konkurs); avantazh (advantage) - (Alb. epërsi, përparësi).

In the newspaper "Bota sot" published on 20.9.2012, page 3, in the article "President Jahjaga gathers in Prishtina world's strongest 200 women", there are in total 521 words, 473 Albanian or $90.79 \%$ and 48 foreign words or $9.21 \%$. Foreign words used in this article: Presidente (president) -(Alb. kryetare); samit (summit)-( Alb.konferencë ), a high level meeting; partneritet (partnership) - (Alb. bashkëpunim-collaboration); medie (media) - (Alb. mjetet e informimit publik means of public information); dekadë (decade) - (Alb. dhjetëvjetësh); tranzicion(transition) - (Alb.kalimtare, fazë, periudhë kalimtare-transitional stage); sakrificë (sacrifice) - (Alb. flijim);

stabilitet (stability) - (Alb. qëndrueshmëri); lider (leader) - (Alb. prijës, udhëheqës); lidership (leadership) - (Alb. kreu, udhëheqësi);

trend (trendy)-(Alb. modë); kurajë (courage) - (Alb. guxim); global (global) -(Alb. botëror); platformë (platform) (Alb. program veprimi);

avancim (advance)-(Alb. përparim); komunikim(communication) -(Alb. njoftim); investim(investment) (Alb.shpenzim i mjeteve); fuqishëm).

sfidë (challenge)-(Alb. vështirësi); eminente (eminence)-(Alb. të rëndësishme); potencial (potential)-(Alb. i

If we analyse the percentages of foreign words in six articles selected from different daily newspapers then we get this lineup, according to highest percentage of foreign words usage in articles:

1. Newspaper "Bota sot" $-9.21 \%$

2. Newspaper "Koha ditore" $-9.20 \%$

3. Newspaper "Kosova sot" $-8.33 \%$

4. Newspaper "Zëri" $-6.27 \%$

5. Newspaper "Shekulli" - 5.15\%

6. Newspaper "Epoka e re" - 3.84\%.

From the research and analyses conducted in our newspapers, in general we can say that about $7 \%$ of the used words are foreign that can be replaced with Albanian words. It is worth mentioning that in some articles the foreign words are repeated several times, which have increased the number of foreign words within the article. With the use of so many foreign words not only the article becomes complicated, but it also increases the possibility that readers will less understand the article. Although a part of these borrowings have been deeply imprinted in Albanian Language, that we do not feel them as foreign words, yet there are some that are unknown and not well understood from many readers. Berani mentions that the frequency of foreign words usage depends on the cultural level of the individual who writes. Those who know foreign languages use foreign words in their writings, or sometimes the opposite happens, those who don't know foreign languages, irresponsibly use foreign words in their writings, that can be easily replaced with Albanian (Berani, 1980: 259). 


\section{Conclusions and Recommendations}

The languages continuously develop, as well as Albanian language, therefore it is necessary that the Albanian language borrows new words, but not those that have an adequate corresponding word in Albanian.

Many authors have highlighted many foreign words that can be replaced with Albanian words, however, foreign words are still being used.

The press, in particular, needs to be more careful, as far as using foreign words, because it affects in spreading and imprinting of the words to the reader. The press should have criteria and responsibilities for the language standard. This problem must be dealt by the scientific and educational institutions, but journalists, writers, publicists, politicians etc. should also help about this issue.

In replacing of the foreign words without a doubt great help can be used from the country folk treasure, dialects and our sub dialects.

At the end the language should be properly spoken and written by the standards of literary norms by each individual without using foreign words when there are Albanian words, with a little care and responsibility, but by a National sensibility, foreign words and specimen can be out of use.

\section{References}

Berisha, N. (2011). Albanian language. No. 2, Prishtina: IAP.

Bejta, M. (1983). Actual problems of the Albanian language culture, Prishtina: IAP.

Berani, Sh. \& Birinxhiku, H. (1989). Albanian word instead of a foreign word, Prishtina: Department of texts and educational equipments of Socialist Autonomous Province of Kosovo.

Berani, Sh. (1980) Issues of literary norm (summary of works) Prishtina: IAP.

Berani, Sh. (1983). Actual problems of the Albanian language culture, Prishtina: IAP.

Berani, Sh. (1983). Albanian language. No. 1, Prishtina: IAP.

Çabej, E. (1980). Issues of literary norm (summary of works), Prishtina: IAP.

Çabej, E. (1987). Language borrowing III, Prishtina: Rilindja.

Dhirmo, A. (1983). Actual problems of the Albanian language culture, Prishtina: IAP.

Dictionary "For the purity of Albanian language". (1998), Tirana: Academy of Science of Republic of Albania.

Gogi, I. (1983). Actual problems of the Albanian language culture, Prishtina: IAP.

Ismajil, Sh. (2011). Albanian language. No. 2, Prishtina: IAP.

Kryeziu, B. (2006). How to write and read correctly. Prishtina: Scholarly book.

Mulaku, R. (2011). Albanian language. No. 1, Prishtina: IAP.

Murati, Q. (2005). Albanological treatise. Prishtina: IAP.

Murati, Q. (2008). Media Language, Prishtina: IAP.

Sinani, A. \& Bulo, S. (1988). National Albanian literary language and our epoch, Tirana: Academy of Science of Republic of Albania

Thomai, J. (1988). National literary language and our epoch, Tirana, Academy of Science of Republic of Albania.

Xhuvani, A. (1968). For the purity of our language, Prishtina, Rilindja.

"President Jahjaga gathers in Prishtina world's strongest 200 women", (2012, September 20), "Bota sot", p. 3.

"The retirees against their law",(2011, December 27) Epoka e re", p. 9,

"Kosovo wins the right to its feasibility study", (2012, February 24), "Koha ditore" p. 19.

"Growth of the global economy, independently from Europe" (2011, December 27) "Kosova sot", p. 6.

"President Topi gathers the Ambassadors and reads the declaration of Lezha" 2012, March 3) "Shekulli" p. 4.

"The government leases $3 \mathrm{~km}$ of beach in Dhërmi", Zëri" (2012, September 19) p. 18. 